\title{
Ik heb niets beters te doen
}

Citation for published version (APA):

de Ruiter, C. (2007). Ik heb niets beters te doen. Maastricht University. https://doi.org/10.26481/spe.20070928cr

Document status and date:

Published: 28/09/2007

DOI:

$10.26481 / \mathrm{spe} .20070928 \mathrm{cr}$

Document Version:

Publisher's PDF, also known as Version of record

\section{Please check the document version of this publication:}

- A submitted manuscript is the version of the article upon submission and before peer-review. There can be important differences between the submitted version and the official published version of record.

People interested in the research are advised to contact the author for the final version of the publication, or visit the DOI to the publisher's website.

- The final author version and the galley proof are versions of the publication after peer review.

- The final published version features the final layout of the paper including the volume, issue and page numbers.

Link to publication

\footnotetext{
General rights rights.

- You may freely distribute the URL identifying the publication in the public portal. please follow below link for the End User Agreement:

www.umlib.nl/taverne-license

Take down policy

If you believe that this document breaches copyright please contact us at:

repository@maastrichtuniversity.nl

providing details and we will investigate your claim.
}

Copyright and moral rights for the publications made accessible in the public portal are retained by the authors and/or other copyright owners and it is a condition of accessing publications that users recognise and abide by the legal requirements associated with these

- Users may download and print one copy of any publication from the public portal for the purpose of private study or research.

- You may not further distribute the material or use it for any profit-making activity or commercial gain

If the publication is distributed under the terms of Article $25 \mathrm{fa}$ of the Dutch Copyright Act, indicated by the "Taverne" license above, 
prof. dr. Corine de Ruiter

Ik heb niets beters te doen 


\section{Colofon}

Basisontwerp en realisatie: Océ Business Services, Maastricht

Foto omslag: Ludo Verschueren

ISBN: $978-90-5681-265-2$

Alle rechten voorbehouden. Niets uit deze uitgave mag worden verveelvoudigd, opgeslagen in een geautomatiseerd gegevensbestand of openbaar gemaakt, zonder voorafgaande schriftelijke toestemming van de auteur of uitgever. 


\section{Ik heb niets beters te doen}

\section{Rede}

In vrije vorm uitgesproken bij de aanvaarding van het ambt van bijzonder hoogleraar Forensische Psychologie aan de Faculteit der Psychologie van de Universiteit Maastricht

op vrijdag 28 september 2007

door

dr. Corine de Ruiter

\section{Universiteit Maastricht}



Mijnheer de Rector, waarde collega's, lieve vrienden en familie,

Op één dag na precies 7 jaar geleden, op 29 september 2000, hield ik mijn oratie ter gelegenheid van mijn benoeming als bijzonder hoogleraar Forensische psychologie aan de Universiteit van Amsterdam (de Ruiter, 2000). De titel van mijn rede toen luidde: 'Voor verbetering vatbaar'. Ik was toen van mening dat er veel te verbeteren was aan de kwaliteit van het werk in de forensische sector. Dat vind ik nog steeds.

Ook toen lag de forensische psychiatrie, en in het bijzonder de TBS-maatregel, onder politiek en maatschappelijk vuur. In mijn rede van 2000 heb ik gepleit voor evidence-based practice in de diagnostiek en de behandeling van psychisch gestoorde delinquenten, in alle fasen van de rechtsgang. Evidence-based betekent letterlijk: gebaseerd op wetenschappelijk bewijs. Soms is dat bewijs helaas nog niet voorhanden, maar de professional dient op zijn minst transparant, toetsbaar en gestructureerd te werk te gaan, zodat inzichtelijk is hoe en waarom hij tot een besluit of advies is gekomen. De invoering en validering van gestructureerde methoden voor risicotaxatie en risicohantering in de afgelopen zeven jaar hebben aan vergroting van die transparantie bijgedragen (zie o.a. Hildebrand \& de Ruiter, 2004; de Ruiter \& Hildebrand, 2007). Toch maak ik mij grote zorgen om de TBS in het bijzonder, maar ook om het Nederlandse strafrechtklimaat in het algemeen.

\section{Steeds meer cellen}

Het maatschappelijke klimaat wereldwijd en ook in Nederland is de afgelopen zeven jaar harder en repressiever geworden; de dramatische moorden op Pim Fortuyn en Theo van Gogh, en de terreuraanslagen in andere Westerse landen, hebben er mede toe geleid dat veiligheid hoog op de Nederlandse politieke agenda is komen te staan. Hoewel Nederland internationaal altijd bekend stond om zijn humane strafrecht, heeft zich de afgelopen 20 jaar ongemerkt een trendbreuk voorgedaan. Zo is het aantal gevangenen per 100.000 inwoners sinds 1985 verviervoudigd, een ontwikkeling die vergeleken kan worden met die in de Verenigde Staten, maar niet met andere West-Europese landen (Boone \& Moerings, 2007).' En hoewel veel leken in Nederland nog steeds schijnen te denken dat een Nederlandse gevangenis meer overeenkomst vertoont met een hotel dan met een middeleeuwse kerker, moet ik hen toch uit de droom helpen. Onze vorige Minister van Justitie, mr. P.H. Donner, heeft onder de eufemistische noemer 'Modernisering Sanctietoepassing' ingrijpende reorganisaties doorgevoerd in ons gevan- 
geniswezen. ${ }^{2} \mathrm{lk}$ zal hier niet ingaan op alle details van die veranderingen, ik volsta met enkele voorbeelden. Zo maken arbeid en onderwijs niet langer deel uit van het standaardregime in de gevangenissen. Vaak zitten gedetineerden 23 van de 24 uren van een etmaal in hun cel. De verhouding tussen gedetineerden en personeel is ongeveer gehalveerd (Boone, 2007), en reïntegratieprogramma's tijdens de detentie worden alleen aangeboden aan een kleine groep gemotiveerde of 'ontvankelijke' gedetineerden. De SOV-maatregel ${ }^{3}$ is vervangen door de ISD-maatregel ${ }^{4}$, de maatregel waarmee veelal verslaafde veelplegers die relatief lichte vergrijpen zoals eenvoudige diefstallen, hebben gepleegd, gedurende twee jaar gedetineerd kunnen worden. De ISD-maatregel heeft als doel veelplegers het plegen van delicten feitelijk onmogelijk te maken door detentie in een zeer beperkt regime. Resocialisatie is geen primair doel van de ISD-maatregel in tegenstelling tot de SOVmaatregel, waar resocialisatie nadrukkelijk als legitimerend hoofddoel was gesteld (Struijk, 2007). Door de meervoudige psychische en sociale problematiek, die kenmerkend is voor de populatie veelplegers, zal de ISD-maatregel door het volledig ontbreken van serieuze gedragsinterventies, vele draaideurcriminelen gaan opleveren.

Voor de meeste gedetineerden is er geen behandeling ín de gevangenis, alleen nazorg ná het ontslag uit de gevangenis. Ook de organisatie van die nazorg is sinds 2004 ingrijpend veranderd. Vroeger was de reclassering daarvoor verantwoordelijk, nu hebben de gemeenten de regierol daarover gekregen. De penitentiaire inrichtingen moeten de overdracht realiseren naar de gemeenten op vier deelgebieden: identiteitsdocumenten, inkomen, huisvesting en zorg. Dit gaat via een basisformulier nazorg dat de penitentiaire inrichting bij de gemeente aanlevert. Zoals de laatste jaren zo vaak in Nederland gebeurt, lijkt men in de Haagse kaasstolp te denken dat met het creëren van zo'n overdrachtsformulier ook de nazorg wel geregeld is. Niets is echter minder waar, zoals enkele recente publicaties en rapporten aantonen (Poort, 2007; Snippe, van der Stoep, van Zwieten, \& Bieleman, 2006; Zwemmer, Jager, \& van Vliet, 2007). Bij veel gedetineerden is sprake van complexe problematiek, zoals een schuldenlast, werkeloosheid, en niet in de laatste plaats: psychische en verslavingsproblemen. In de meeste gemeenten is geen sprake van een regie op de uitvoeringspraktijk van de nazorg, waardoor afglijden richting criminaliteit voor ex-gedetineerden snel op de loer ligt. Juist in het nazorgtraject heeft de reclassering een belangrijke taak, die nu volledig weggesneden is uit haar takenpakket. Uit de wetenschappelijke literatuur over rehabilitatie en reïntegratie van delinquenten komt 
het gunstige effect van een geleidelijke terugkeer naar de maatschappij vanuit gesloten inrichtingen, zoals gevangenissen en forensisch psychiatrische psychiatrische instituten naar voren (Brown, O'Grady, Battjes, Farrell, Smith, \& Nurco, 2001; Harvey, Shakeshaft, Hetherington, Sannibale, \& Mattick, 2007; Swanson, Swartz, Borum, Hiday, Wagner, \& Burns, 2000).

Donner's beleid tart alle wetenschappelijke evidentie over 'What Works' (Andrews \& Bonta, 2003) om criminele recidive tegen te gaan. De nadruk op repressie, met opsluiting in de moderne varianten van kerkers, als basale overheidsstrategie om criminaliteit te beheersen is volledig achterhaald en in strijd met de wetenschappelijke kennis die de psychologie de laatste decennia heeft voortgebracht. Het komende half uur ga ik u uitleggen waarom:

(1) Ten eerste, worden onze gevangenissen overwegend bevolkt door psychisch gestoorde en verslaafde patiënten, en niet door inherent slechte mensen die in staat zijn zelf verantwoordelijkheid te dragen voor hun misdaden, zoals het uitgangspunt van het strafrecht is;

(2) Ten tweede zijn er de vele schadelijke gevolgen van de detentie zelf, vooral de langdurige, op het psychische welzijn van de gedetineerden én op de personen die er werken. Als het enigszins kan, dient gevangenisstraf vermeden te worden;

(3) Ten derde, dient de behandeling van psychische stoornissen, inclusief verslavingsproblemen, centraal te staan in een effectief criminaliteitsbeleid. Daarbij dient er speciaal aandacht te zijn voor en geïnvesteerd te worden in de preventie van criminaliteit en geweld bij kinderen en jeugdigen.

\section{Mad vs. bad}

Naast een toename van het aantal cellen in gevangenissen, is er het afgelopen decennium ook een ongekende toename van het aantal bedden in forensisch psychiatrische inrichtingen te zien: in 1995 waren er 650 TBS-plaatsen tegenover ruim 1600 in 2005 (www.dji.nl).

formele capaciteit TBS-inrichtingen ultimo $1995-2005$

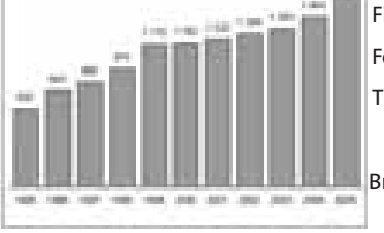

Figuur 1.

Formele capaciteit in aantal bedden in Nederlandse TBS-inrichtingen (1995-2005) 
De meeste Westerse strafrechtsystemen maken een onderscheid tussen 'mad' en 'bad'. Alleen 'bad' delinquenten verdienen straf in deze systemen, de 'mad' zijn ontoerekeningsvatbaar en moeten behandeld worden in een forensisch psychiatrische kliniek. In Nederland maakt men ook nog onderscheid in vijf verschillende gradaties van ontoerekeningsvatbaarheid, maar deze verfijning mist elke wetenschappelijke basis (de Ruiter \& Hildebrand, 2003). En wat nog veel verontrustender is, althans voor de rechtsgeleerdheid, is dat ook het hele concept toerekeningsvatbaarheid door recente resultaten uit de neurowetenschappen twijfelachtig is geworden (Burns \& Bechara, 2007).

Het concept toerekeningsvatbaarheid is gekoppeld aan het begrip 'vrije wil'. Dit eeuwenoude concept (zie Carey, 2007 voor een historisch en filosofisch overzicht) gaat ervan uit dat de mens keuzevrijheid heeft, en dat hij er dus verantwoordelijk voor gehouden dient te worden als hij verkeerde keuzes maakt. Als die keuzes in strijd zijn met de strafwet kan langdurige gevangenzetting opgelegd worden, als straf voor het misbruik van de keuzevrijheid.

Ik geef nu een aantal voorbeelden van onderzoek waaruit blijkt dat de vrije wil op zijn hoogst een illusie is, maar eigenlijk niet bestaat. Ten eerste zijn er de experimenten van Benjamin Libet (Libet, 1985). Libet vond dat het bewustzijn van de intentie om een vinger in beweging te zetten weliswaar voorafgaat aan die beweging, maar dat ongeveer 400 milliseconden voorafgaand aan de beleving van de bewuste intentie al sprake is van voorbereidende hersenactiviteit. Hersenactiviteit gaat dus vooraf aan de bewuste intentie én aan de handeling; de bewuste intentie zelf is niet de oorzaak van de handeling. De bekende psycholoog Daniel Wegner noemt het idee van de vrije wil daarom een mentale illusie (Wegner \& Wheatley, 1999).

Een tweede onderzoek dat de bewuste vrije wil in twijfel trekt, is de zogenaamde lowa Gambling Taak (IGT; Bechara, Damasio, Tranel, \& Damasio, 1997). Bij deze Taak krijgen proefpersonen vier stapels kaarten en 2000 dollar om het spel te spelen met als doel zoveel mogelijk geld te winnen. Elke keer als de proefpersoon een kaart trekt, wint of verliest hij een bepaald bedrag aan geld. De stapels A en B zijn nadelig omdat de onmiddellijke beloning hoog is (100 dollar), maar de verliezen groot zijn. Op de lange duur leiden deze stapels tot verlies van al je geld. De stapels C en D zijn voordelig; de beloningen per kaart zijn lager (50 dollar), maar de verliezen kleiner, zodat op termijn winst gemaakt wordt. Tijdens het spelen van de IGT wordt de huidgeleidingsrespons (Skin Conductance Reaction) vastgelegd om niet-bewuste reacties te 
meten. De proefpersonen wordt ook gevraagd op verschillende momenten tijdens de IGT aan te geven of ze het spel begrijpen, dus of ze een bewuste strategie hanteren. De resultaten van dit experiment wijzen uit dat beslissingen worden beïnvloed door automatische, emotionele processen, door Antonio Damasio 'somatic markers' genoemd (Damasio, 2003). Normale proefpersonen gaan al kaarten uit de voordelige stapels kiezen vóórdat ze een bewuste strategie hebben ontwikkeld over welke stapels voordelig zijn. Ze vertonen een anticipatoire huidgeleidingsrespons vlak voordat ze een kaart uit de nadelige stapels trekken; onbewust 'weet' het lichaam als het ware dat deze stapels onvoordelig zijn, maar de proefpersonen rapporteren dat op een bewust niveau nog niet. Het meest interessante is nog wel dat zelfs personen die tijdens de hele IGT nooit bewust ontdekken hoe de IGT werkt, toch de voordelige keuzes maken en geld winnen. Onbewuste, automatische processen zijn dus verantwoordelijk voor het maken van keuzes die op de lange termijn voordelig zijn. Er zijn ook groepen personen die heel slecht zijn in de lowa Gambling Task; zij blijven kiezen uit de nadelige stapels, zelfs als ze bewust weten welke strategie hun winst oplevert! Dit geldt bijvoorbeeld voor personen met tweezijdige schade aan de prefrontale hersenkwab en ook voor personen die verslaafd zijn (Bechara, Dolan, \& Hindes, 2002). Hun brein behoedt hen als het ware niet meer voor de verkeerde keuzes.

Ikzie $u$ allen nu denken-maar als dit soort beslissingen gestuurd wordt door automatische processen, hoe moet het dan met het strafrecht? De psychopaat, die bewust agressie gebruikt om zijn kwaadaardige doelen te bereiken, die is toch zeker wél verantwoordelijk voor zijn geplande gewelddadige acties? Die is toch juist het prototype van de inherent slechte ('bad') delinquent? Ook bij deze aanname zet recent psychologisch onderzoek vraagtekens. Psychopathische kinderen én volwassenen vertonen een verminderde verwerking van negatieve emotionele prikkels, zoals verdrietige en angstige gezichten, in vergelijking met normalen (Blair, 2003; Blair, Colledge, \& Mitchell, 2001; Deeley et al., 2006). Ze verwerken deze prikkels alsof het neutrale prikkels zijn. Verschillende studies hebben deze afwijkingen in de verwerking van emoties gekoppeld aan een verminderde functie van de amandelkernen (amygdala) in het brein van psychopaten (Birbaumer et al., 2005; Kiehl et al., 2001; Tiihonen et al., 2000). De amandelkernen vormen een evolutionair oude hersenstructuur die verantwoordelijk is voor de primaire somatische reactie op aversieve prikkels. Het gebrek aan empathie dat wij klinisch observeren bij de psychopaat hangt waarschijnlijk samen met dit amygdala-defect. De psychopaat ervaart geen angst als hij geconfron- 
teerd wordt met de pijn van zijn slachtoffers, de negatieve consequenties van zijn daden beangstigen hem niet en als hij uiteindelijk bestraft wordt is hij ook daar weinig gevoelig voor (Blair, 1995; 2001). Maar is hij 'bad', zoals politici als Wilders en Eerdmans ons zo graag willen doen geloven? De psychologie zet daar vraagtekens bij.

In de dagelijkse Nederlandse strafrechtspraktijk blijkt het onderscheid tussen 'bad' en 'mad' al veel langer niet goed te werken, getuige de grote aantallen psychisch gestoorde gedetineerden die onze gevangenissen bevolken. Als het strafrecht consequent functioneerde zouden de 'mad' immers in de (forensisch) psychiatrische inrichtingen moeten zitten, en niet in de gevangenis. In Nederland zijn enkele studies uitgevoerd naar de prevalentie van psychische stoornissen onder gemengde groepen gedetineerden. Zo vonden Schoemaker en Van Zessen (1997) dat $71 \%$ van de gedetineerden in Penitentiair Complex Scheveningen in het voorafgaande jaar voldeed aan de criteria van een psychische stoornis volgens het psychiatrische classificatiesysteem DSM-III-R. Bulten (1998) vond dat eenderde van de kortgestrafte gedetineerden in de Penitentiaire Inrichting Nieuw-Vosseveld een DSM symptoomstoornis, anders dan een verslavingsstoornis, had in het voorafgaande jaar. Tweederde van deze steekproef had een verslavingsstoornis. Rond de $5 \%$ van de gedetineerden lijdt aan een psychotische stoornis, ongeveer 13 maal zo veel als onder de algemene bevolking voorkomt (Bulten \& Van Kordelaar, 2005).

Als zo'n groot percentage van de personen die door het plegen van delicten met justitie in aanraking komt, lijdt aan een psychische stoornis, lijkt mij de vraag gerechtvaardigd hoe dat komt. Recente rapporten van de Gezondheidsraad (2006) en de Raad voor Maatschappelijke Ontwikkeling (RMO, 2007) wijzen op mogelijke oorzaken, zoals de vermaatschappelijking van psychiatrische patiënten (lees: het sluiten van de chronische afdelingen van psychiatrische inrichtingen), de afname van kennis en ervaring met agressieve patiënten in de algemene psychiatrie en het gebrek aan effectieve interventies voor antisociale kinderen in de jeugdzorg. Ik denk dat al deze factoren inderdaad een rol spelen; ik zie ze ook steeds terug in de biografieën van de forensische patiënten die ik in de loop der jaren als psychodiagnosticus heb onderzocht. Personen die uiteindelijk in de TBS of de gevangenis belanden in verband met een ernstig misdrijf hebben vaak al een jarenlange en ineffectieve gang door de hulpverlening achter de rug (van Vliet \& Oei, 2006). ${ }^{5}$ De Gezondheidsraad en de RMO komen met voor de hand liggende adviezen, zoals: 'verbeter de aansluiting tussen straf- en 
zorginterventies' en 'investeer meer in de preventie van antisociaal gedrag.' Beide rapporten verzuimen echter één zeer fundamentele vraag te stellen, namelijk waarom de houding van de maatschappij als geheel ten aanzien van externaliserend (antisociaal) probleemgedrag zo bestraffend is, terwijl internaliserende problematiek, zoals depressies en angststoornissen, met een zorgende houding worden benaderd. Voor angststoornissen en eetstoornissen hebben wij speciale klinieken in Nederland; voor allerlei vormen van delinquent gedrag hebben we gevangenissen waar nauwelijks behandeling, laat staan specialistische behandeling, plaatsvindt. Zo zijn we via een omweg weer bij het achterhaalde concept van de vrije wil beland - antisociaal gedrag wordt gezien als de verantwoordelijkheid van de persoon zelf, een depressie of een angststoornis niet, daar voor kun je hulp krijgen.

Juristen zullen nu misschien tegenwerpen dat een maatschappij met een strafrechtsysteem dat het concept van de vrije wil en de individuele verantwoordelijkheid loslaat, ten dode is opgeschreven en alleen kan uitmonden in totale anarchie. Dat hoeft echter niet. Ik moet toegeven: een klassiek strafdoel als vergelding is zinloos, in het licht van de recente psychologische onderzoeksbevindingen. Wie verdient er immers straf als het criminele gedrag het resultaat is van automatische neurale processen? Een strafdoel als rehabilitatie, namelijk het voorkómen van nieuwe misdrijven, kan echter belangrijker worden. Als het fundamentele psychologische onderzoek, zoals dat van Blair naar de aard van de stoornis psychopathie, leidt tot klinische toepassingen kunnen effectieve behandelingen ontstaan. Tenslotte wil ik nog de recente ontwikkeling van het zogenaamde herstelrecht (restorative justice) binnen de strafrechtspleging noemen. Vooral in de Verenigde Staten, maar ook in Vlaanderen, wint deze aanpak terrein (Forgays \& DeMilio, 2005; Koss, Bachar, Hopkins, \& Carlson, 2004). Walgrave (2005) omschrijft herstelrecht als een visie op recht doen die prioriteit geeft aan het herstel van de schade, leed en sociale onrust die door een misdrijf zijn ontstaan. Waar binnen het traditionele strafrecht vergelding als primair doel wordt benoemd, ligt het doel van herstelrecht in het herstel van de aangerichte schade. Leedtoevoeging wordt niet nagestreefd, maar kan wel een neveneffect zijn. De praktijk van het herstelrecht sluit beter aan bij de inzichten uit de neurowetenschappen omdat het minder op vergelding is gericht, en delicten ziet als resultaat van psychologische en sociale factoren. 


\section{De sociale psychologie van de gesloten inrichting}

'Van elk fatsoenlijk mens valt een duivel te maken', staat er boven een interview met de Amerikaanse sociaal psycholoog Philip Zimbardo in de Elsevier van 4 december 2006. ${ }^{6}$ Normale mensen kunnen onder de verkeerde omstandigheden veranderen in martelende beulen. Dat bewees Zimbardo, samen met zijn student Craig Haney, in het beroemde Stanford Prison Experiment (Haney, Banks, \& Zimbardo, 1973). ${ }^{7}$ Hoe ging dat experiment in zijn werk? Mannelijke universiteitsstudenten reageerden op een krantenadvertentie waarin opgeroepen werd tot deelname aan een psychologisch onderzoek naar 'het leven in een gevangenis'. Deelname aan de studie zou 1 à 2 weken duren en werd beloond met 15 dollar per dag (gecorrigeerd voor inflatie zou dat nu ongeveer 70 dollar zijn; Carnahan \& McFarland, 2007). De 75 studenten die reageerden op de advertentie werden geïnterviewd over hun psychische gezondheid, voorgeschiedenis van psychiatrische aandoeningen in de familie, en eerder antisociaal gedrag. De 24 lichamelijk en mentaal meest stabiele studenten werden geselecteerd en vervolgens willekeurig toegewezen aan de rol van gevangene of bewaker.

In de gesimuleerde gevangenisomgeving, die was nagebouwd in de kelder van de psychologiefaculteit, bleek zich al snel een ethisch onhoudbare situatie te ontwikkelen. De studenten in de bewakersrol maakten misbruik van hun macht door vernederend en sadistisch gedrag tegen de gevangenen. Sommige gevangenen reageerden met blinde gehoorzaamheid op het autoritaire gedrag van de bewakers, anderen smeekten in paniek om te worden vrijgelaten. Het geplande experiment moest na 6 dagen worden afgebroken omdat de nep-gevangenis de proefpersonen op dramatische wijze veranderde in machteloze gevangenen (waarvan een deel psychisch instortte) en sadistische bewakers (zie www.prisonexp.org voor details van de studie). Het gebruik van fysiek geweld tijdens het experiment was niet geoorloofd, dus werden de gevangenen geestelijk mishandeld.

Het pathologiserende effect van een gevangenisomgeving, maar eigenlijk van iedere geïnstitutionaliseerde omgeving, op het gedrag van de mensen die erin verkeren, is door het Stanford Prison Experiment pijnlijk duidelijk geworden. ${ }^{8}$ De mishandeling van Iraakse gevangenen door jonge Amerikaanse soldaten in de Abu Ghraib gevangenis in 2004 kan als een déjà-vu beschouwd worden. In mijn contacten met gedetineerden in Nederlandse gevangenissen zie ik vooral de laatste tijd helaas soms dezelfde destructieve processen. Ik geef een voorbeeld. Piet is een 35-jarige drugsverslaafde die onder de ISD-maatregel al 
anderhalf jaar in de gevangenis verblijft. In de loop van die anderhalf jaar is hij, door het volledig ontbreken van perspectief op verandering, afgegleden in een depressie. Hij komt zijn cel niet meer uit, ligt de hele dag op bed, vertrouwt binnen de gevangenismuren niemand meer. Als ik in het kader van een opdracht van de rechter-commissaris in een andere strafzaak, waarin Piet als getuige is verhoord, naar hem toekom om hem psychologisch te onderzoeken, treedt hij mij met diezelfde achterdocht tegemoet. Ik laat hem uitrazen, zijn verhaal vertellen, kortom, ik luister. Hij begint te vertellen over zijn 3-jarige dochtertje en zijn oude moeder, die hij zoveel verdriet heeft aangedaan met deze lange gevangenisstraf. En na een uur zegt hij: 'ik wil u nog wel een keer spreken'. In de loop van het onderzoek, dat zich over een aantal weken afspeelt, schrijft Piet mij verschillende brieven waarin hij zich uit over zijn onmacht en frustraties over de bejegening in de gevangenis. De brieven lezen als noodkreten van een mens die niet meer weet waar hij het moet zoeken en de enige aanpak die het gevangenispersoneel kent is repressie, door Piet te isoleren en hem privileges af te nemen. Uiteraard werkt deze aanpak niet en escaleert de situatie alleen verder.

Beloning van positief gedrag is effectiever dan louter straffen van ongewenst gedrag. Opvoed programma's op televisie, zoals 'Schatjes' en 'De Nanny', werken met deze interventie. Dit soort 'wetten' uit de sociale leertheorie zouden ook binnen het gevangeniswezen toegepast moeten worden, het zou het leefklimaat in de inrichtingen sterk verbeteren. ${ }^{9}$ Psychologen, en dan in het bijzonder gedragstherapeuten, zouden uitstekende gevangenisdirecteuren kunnen zijn (de Ruiter, 2007c), maar dan moeten beleidsmakers en politici ruimte creëren voor een positieve, op preventie en rehabilitatie gerichte aanpak van criminaliteit (Haney \& Zimbardo, 1998; Haney, 2006).

Dat de insititutionele omgeving onwenselijke en schadelijke effecten kan hebben op het gedrag van het beheerspersoneel dat er werkt, wordt vaak nog wel erkend, maar dat ook professionele gedragsdeskundigen die in dit type instituties werken niet immuun zijn hiervoor, realiseren deze professionals zich nog te weinig. Een ander prachtig sociaal psychologisch experiment, ook uit de jaren '70, werpt hier licht op. David Rosenhan (1973) liet acht pseudopatiënten (drie vrouwen, vijf mannen) zich aanmelden bij 12 verschillende psychiatrische ziekenhuizen verdeeld over vijf staten aan de Oost- en Westkust van de VS. Alle patiënten hadden als aanmeldingsklacht het horen van stemmen. Behalve het voorwenden van dit symptoom en het opgeven van een valse naam en beroep, wijzigden de proefpersonen geen andere zaken in hun 
levensgeschiedenis. Onmiddellijk na de opname op de psychiatrische afdeling stopten de pseudopatiënten met het simuleren van de symptomen; ze gedroegen zich weer 'normaal'. Desondanks werd geen van de pseudopatiënten ontdekt! De meeste patiënten kregen de diagnose schizofrenie, en bij ontslag (gemiddeld na 19 dagen opname) kregen ze de diagnose schizofrenie, 'in remissie'. Een opvallende bevinding was dat ongeveer een kwart van de medepatiënten op de opnameafdelingen wél doorhad dat er iets aan de hand was. Zij zeiden tegen de pseudopatiënten: "You are not crazy. You are a journalist or a professor. You're checking up on the hospital" (p. 252). Rosenhan's studie laat zien hoe krachtig psychiatrische labels zijn. Als de patiënt eenmaal het label schizofreen heeft, worden de waarnemingen van het personeel daar volledig door gekleurd. Een voorbeeld kan dit illustreren. Alle pseudopatiënten maakten in het openbaar aantekeningen tijdens de klinische opname. Rosenhan had van te voren verwacht dat dit veel achterdocht zou wekken bij het personeel van de inrichtingen. Niets bleek minder waar: in de dossiers van de verpleging stond het schrijven vermeld als teken van het pathologische gedrag van de patiënten!

Rosenhan's studie laat op pijnlijke wijze zien hoe blind de gedragsdeskundige die in een institutionele setting werkt kan zijn; blind voor gezond gedrag van de patiënt, omdat het niet past in zijn al eerder gevormde beeld. Dit wordt ook wel confirmation bias genoemd (Jelicic \& Merckelbach, 2006). Dit fenomeen doet zich a fortiori voor binnen een forensische context. Als een verdachte wordt aangemeld voor een forensisch gedragskundig onderzoek weet de professional immers van welk strafbaar feit de persoon wordt verdacht. De psycholoog of psy-

chiater moet voorzichtig te werk gaan bij het stellen van een diagnose; dit geldt nog sterker als sprake is van een verdachte die het plegen van het delict ontkent (de Ruiter, 2007a). Wij kennen in Nederland ambulante en klinische forensische gedragskundige rapportages, de laatsten worden overwegend binnen het Utrechtse Pieter Baan Centrum (PBC) verricht. Ook het PBC is een insititutionele setting, met alle risico's van dien. Het PBC hecht traditioneel sterk aan de subjectieve, klinische interpretaties van de gedragsobservaties gedurende de opname in het PBC. Die gedragsobservaties worden vervolgens bijna uitsluitend geïnterpreteerd in termen van de persoonlijkheid van de verdachte, maar bijna nooit als functie van de wisselwerking tussen de persoonlijkheid van de verdachte en de context van de institutionele setting (Brand, 2001; Crombag, van Koppen, \& Wagenaar, 2005; Derks, 2001; Jelicic \& Merckelbach, 2006). 
In ieder diagnostisch proces moet expliciet rekening gehouden worden met de context waarin de onderzochte persoon zich bevindt (zie Figuur 2).

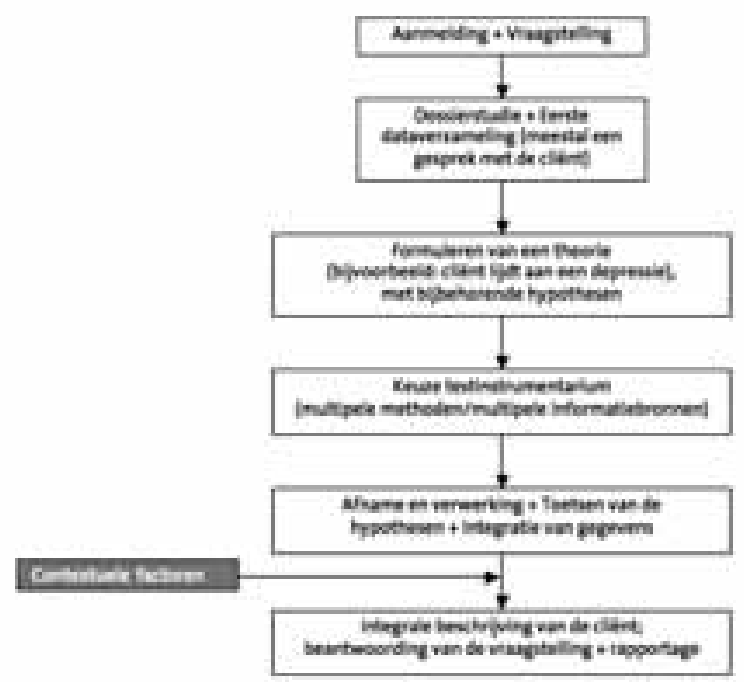

Figuur 2. Fasen in het diagnostische proces.

Overgenomen uit: C. de Ruiter \& M. Hildebrand (Red.), Handboek Psychodiagnostiek: Van testmethode naar toepassing. Amsterdam: Harcourt, 2006 (p. 12).

Juist omdat de diagnostische conclusies die in forensische gedragskundige rapportages staan, zulke vergaande gevolgen kunnen hebben voor de onderzochte persoon in het kader van de rechtsgang, moeten er extra hoge kwaliteitseisen aan gesteld worden. Immers, op basis van deze rapportages worden volwassenen veroordeeld tot TBS met dwangverpleging, jeugdigen tot een PIJ-maatregel en worden TBS-gestelden op een longstay afdeling geplaatst. Helaas kennen wij binnen ons strafrecht geen Frye ${ }^{10}$ of Daubert standaard", zoals in de VS, waaraan uitspraken van forensische experts moeten voldoen. Ook zijn er geen specifieke beroepsethische richtlijnen voor forensische gedragskundigen zoals de Specialty Guidelines for Forensic Psychologists van de American Psychological Association (Committee on Ethical Guidelines for Forensic Psychologists, 1991), waarin vermeld wordt dat forensisch psychologen een bijzondere verantwoordelijkheid dragen hun rapportages te documenteren, zodat een onafhankelijke reviewer kan bepalen of het onderzoek betrouwbaar 
en valide is uitgevoerd. De mening van een getuigedeskundige die niet berust op objectieve gegevens en wetenschappelijke principes voldoet niet aan deze eisen (Bush, Connell, \& Denney, 2006). Helaas geldt dat op dit moment nog voor té veel gedragskundige forensische rapportages in Nederland. ${ }^{12}$ Diagnostische uitspraken en conclusies zijn vaak onvoldoende onderbouwd met bewijzen van concrete symptomen, informatie uit de levensloop verkregen van derden die de persoon goed kennen en de resultaten van objectieve psychologische tests. Alleen wanneer informatie uit meerdere bronnen en meerdere typen instrumenten de aanwezigheid van een symptoom bevestigt, mag geconcludeerd worden dat het aanwezig is. Men dient de psychiatrische diagnose te stellen aan de hand van gevalideerde semi-gestructureerde interviews op basis van een algemeen aanvaard classificatiesysteem voor psychische stoornissen, zoals de DSM-IV of de ICD-10, in plaats van op basis van globale klinische indrukken (Slobogin, 2007). ${ }^{13}$ Alleen door een toetsbare werkwijze zullen gerechtelijke dwalingen als gevolg van dubieuze rapportages door gedragsdeskundigen zoveel mogelijk vermeden kunnen worden (Gudjonsson \& Young, 2006; de Ruiter, 2007a).

\section{Preventie, preventie en nog eens preventie}

Dat repressie en vergelding ineffectieve strategieën zijn om delinquenten van het slechte pad af te helpen is al jaren bekend. De criminele recidive na gevangenisstraf is zeer hoog ${ }^{14}$, nog hoger dan die onder ex-TBS-gestelden, hoewel de media met hun incidenten-honger ons soms anders willen doen geloven. Maar wat werkt dan wél? Preventie werkt, vooral in de vorm van behandeling van de psychische problemen die ten grondslag liggen aan het criminele gedrag (zie o.a. McGuire, 2002; de Ruiter \& Veen, 2005; de Ruiter, Veen, \& Greeven, 2005). Het betreft veelal gedragsinterventies die gericht zijn op vermindering van impulsiviteit en agressie, vergroting van sociale competenties en vermindering van verslavingsproblematiek. Ook een gerichte behandeling met farmaca kan effectief zijn (zie ook de Ruiter, 2007b).

De staat Washington, in het Noord-Westen van de Verenigde Staten, heeft een aantal jaren geleden een rigoureuze keuze gemaakt voor een op preventie gericht sanctiebeleid, gebaseerd op kosten-effectiviteitsanalyses (zie www.wsipp.wa.gov). Dat werpt inmiddels zijn vruchten af. In oktober 2006 werd een rapport met een meta-analyse gepubliceerd waaruit blijkt dat men de bouw van twee nieuwe gevangenissen (bouwkosten: 250 miljoen dollar per gevangenis en 45 miljoen aan jaarlijkse exploitatiekosten) kan vermijden door een grote investering in 
evidence-based interventies gericht op preventie en terugvalpreventie van delinquentie te doen (Aos, Miller, \& Drake, 2006). Niet alle interventies die deze auteurs onder de loep namen in hun analyse waren echter effectief. Onder de niet-effectieve programma's bevonden zich (voor jeugddelinquenten) bijvoorbeeld: 'wilderness challenge', scared Straight en intensieve reclasseringsbegeleiding. Ook bij volwassen delinquenten is alleen toezicht niet effectief. Toch wordt door Nederlandse politici nog steeds met enige regelmaat voor dit soort maatregelen tegen ontspoorde jeugdigen gepleit.
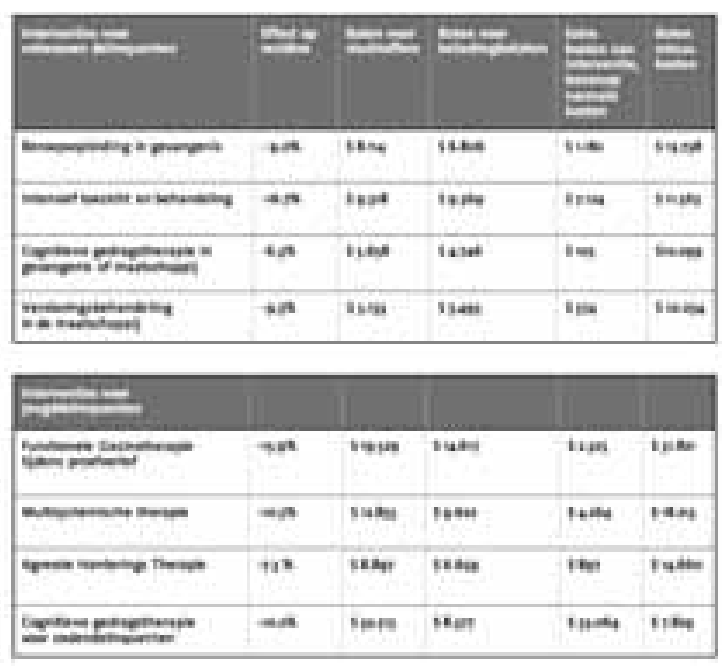

Tabel 1. Wat Werkt: Kosten en Baten ${ }^{1}$ (Aos et al., 2006)

${ }^{1}$ Deze tabel bevat slechts een klein deel van de interventies die door Aos et al. (2006) zijn onderzocht, en dienen slechts als voorbeeld

Daarnaast blijkt het erg belangrijk om de behandelintegriteit van de interventies continu te controleren en te waarborgen. Zo vond Barnoski (2002) dat Functionele Gezinstherapie gegeven door competente therapeuten leidde tot een recidivevermindering van 30\% bij jeugdige delinquenten. Er bleken echter ook therapeuten te zijn die een lage competentie hadden, en hun effectiviteit in termen van recidivevermindering was o. De cijfers in Tabel 1 geven steeds een vergelijking met de effecten van een kale sanctie weer. We zien uit de Tabel dat vooral bij jeugdige delinquenten veel winst te behalen is door gerichte gedragsinterventies, zoals Functionele Gezinstherapie en Multisystemische Therapie, in te 
zetten. Inmiddels vindt er in Nederland implementatie plaats van deze twee behandelmethoden, binnen de (forensische) jeugdpsychiatrie (Breuk, van Dam, Disse, \& Doreleijers, 2005; Limbos et al., 2007).

Voor nóg jongere kinderen met externaliserende gedragsproblemen en delinquenten 'in de dop' worden in Nederland inmiddels op een aantal plekken in de jeugdzorg in het buitenland bewezen werkzame behandelmethoden toegepast. Ik denk hierbij aan methoden als Triple $\mathrm{P}$, Minder boos en opstandig en natuurlijk ook aan Parent Management Training Oregon (PMTO; zie www.pmto.nl), die allemaal via het aanleren van effectieve opvoedingsstrategieën aan ouders de gedragsproblemen van kinderen verminderen. PMTO onderscheidt zich van de andere interventies door een individuele aanpak in plaats van de gangbare groepsgerichte benadering, en door een zeer streng systeem van kwaliteitscontrole en checks op de behandelintegriteit (Berger \& van Everdingen, 2006). De komende jaren zullen wij in een steekproef van 228 kinderen, die worden behandeld in vier jeugdzorginstellingen verspreid over Nederland, vanuit de Universiteit Maastricht in een Randomized Controlled Trial gaan onderzoeken of PMTO effectiever is dan het huidige aanbod voor deze doelgroep. Het volgen van deze kinderen op de lange termijn, tot in hun volwassenheid, staat natuurlijk hoog op ons onderzoeks-verlanglijstje, omdat dit veel inzichten kan bieden in de factoren die afglijden richting criminaliteit voorkómen. Lange termijn follow-up studies van groepen kinderen (of ouders van die kinderen) die een interventie hebben ondergaan, zijn in Nederland bijzonder schaars, omdat de subsidie horizon vaak maar vier jaar betreft. Ook de Gezondheidsraad (2006) pleitte in haar rapport over de antisociale persoonlijkheidsstoornis voor het uitvoeren van langlopend onderzoek naar het effect van dit type preventieve interventies en naar de kosten-effectiviteit ervan.

Effectieve criminaliteitspreventie betekent ook dat de intergenerationele overdacht van huiselijk geweld, in de vorm van kindermishandeling en relationeel geweld, zoveel als mogelijk wordt tegengegaan. Daaraan heb ik de afgelopen jaren onder andere een bijdrage geleverd door het ontwikkelen van een gestandaardiseerd instrument voor risicotaxatie bij kindermishandeling, de CARE-NL (de Ruiter, 2006; de Ruiter \& de Jong, 2006). De komende jaren zullen professionals in de Nederlandse jeugdzorg in dit instrument worden opgeleid, want alleen een deskundige hantering van wetenschappelijk onderbouwde instrumenten garandeert een verbetering ten opzichte van de ongestructureerde klinische blik. De komende jaren zullen wij in een nieuw te starten onderzoekproject een screeningsversie van de CARE-NL ontwikkelen, waar- 
mee professionals als wijkverpleegkundigen, peuterspeelzaalleidsters en basisschoolleerkrachten, die in hun werk natuurlijk veel kinderen zien, gevallen van mogelijke kindermishandeling nauwkeuriger kunnen signaleren (de Ruiter \& Öry, 2006).

\section{De Maastrichtse uitdaging}

Ik heb in deze rede geschetst hoe kennis vanuit de psychologie gebruikt kan worden om de criminaliteit in onze maatschappij effectiever en humaner te verminderen dan op dit moment gebeurt. Ik ben daarmee (althans binnen dit tijdsgewricht) politiek incorrect, maar wel wetenschappelijk verantwoord en tegen 'de harde aanpak'. De Universiteit Maastricht heeft het lef gehad om mij als 'tegendraadse jongere' te benoemen, en ik voel mij hier na anderhalf jaar al helemaal ingeburgerd. De kansen en uitdagingen op forensisch gebied in het Zuid-Limburgse heuvelland zijn groot, en ik zal mijn expertise duurzaam hiertoe inzetten. Concreet betekent dit dat ik mij zal inspannen voor het vestigen van een twee-jarige Masteropleiding Forensische Psychologie aan onze Faculteit. De geplande samenwerking met forensisch-psychiatrische instituten als De Rooyse Wissel biedt volop mogelijkheden voor onderzoek en opleiding, waar ik mij erg op verheug. En dan is er uiteraard de nog grotere ambitie om te komen tot de ontwikkeling van een Maastricht Forensisch Instituut, waarin de forensische wetenschappen in brede zin vertegenwoordigd zijn. Dit initiatief, onder leiding van collega Ton Broeders, kan een belangrijke bijdrage gaan leveren aan 'fair trial' in Nederland en biedt ook kansen voor interessante samenwerking tussen verschillende forensische disciplines.

Leden van het College van Bestuur van de Universiteit Maastricht en van het bestuur van de Faculteit der Psychologie, ik waardeer het zeer dat $u$ niet alleen hebt ingestemd met de vestiging van deze leerstoel aan deze universiteit, maar dat $u$ het belang van de forensische psychologie binnen het geheel van de forensische wetenschappen actief met woord en daad ondersteunt. In de anderhalf jaar dat ik nu verbonden ben aan de UM heb ik kunnen meewerken aan de start van een aantal belangrijke initiatieven op forensisch terrein en ik hoop en verwacht daarvan op termijn samen met $u$ de vruchten te plukken.

Waarde collega's van de Capaciteitsgroep Clinical Psychological Science, jullie zijn het je zelf misschien niet bewust, omdat jullie al langer in deze bijzondere, stimulerende omgeving vertoeven, maar de Maastrichtse 
psychologie is door de combinatie van hoge intellectuele ambitie en Bourgondische joie-de-vivre beslist verslavend. Ik voel mij uitgedaagd en tegelijkertijd in een warm bad. Mijn partner Ferkó is mijn getuige, $u$ kunt het hem zelf vragen: na een paar dagen Maastricht kom ik steeds vol energie naar Utrecht terug.

Waarde collega's van de Interfacultaire Werkgroep Rechtspsychologie, jullie hebben mij als klinisch psycholoog, en dus een beetje een vreemde eend te midden van voornamelijk experimentele rechtspsychologen, in jullie gelederen verwelkomd. Sinds die eerste dagen in de Voerstreek heb ik genoten van de wetenschappelijke 'drive' en de persoonlijke betrokkenheid onder de junior-psychologen. En last but not least, voel ik mij bijzonder bevoorrecht in het intellectueel stimulerende gezelschap te verkeren van senior-psychologen als Hans Crombag, Peter van Koppen, Han Israëls, Marko Jelicic en Harald Merckelbach. Hans, als nestor van onze groep, hoop ik dat ik je met deze rede heb laten zien dat ik niet slechts een aanhanger ben van de psychologie van de individuele verschillen, maar ook het experiment (in casu het experiment in de sociale psychologie) een warm hart toedraag. Harald, wij kennen elkaar al meer dan 25 jaar, vanuit onze studie in Utrecht. Toevallig zijn we beiden in de loop der jaren van de angststoornissen in de criminaliteit beland. Ik herken je passie en snelheid van toen, en ik vind het geweldig om na al die jaren met jou in deze (andere) werkgroep te zitten!

Dames en heren studenten, de afgelopen anderhalf jaar heb ik met veel plezier lesgegeven in de forensische psychologie aan studenten in de Research Master Abnormal Psychology. Nu ik sinds 1 juli vier dagen per week in Maastricht werk, komen daar nog nieuwe cursusblokken bij. Het scientist-practitioner model staat centraal in mijn loopbaan. Dat past denk ik erg goed bij het probleemgestuurde onderwijs aan de UM, waar immers het zoeken van wetenschappelijke oplossingen voor praktische problemen geoefend wordt. De vestiging van een twee-jarige Master Forensische psychologie aan de UM zie ik als een belangrijk doel voor de komende tijd, want ik weet dat vele studenten daar belangstelling voor hebben.

De Raad van Bestuur van het Trimbos-instituut, in het bijzonder Jan Walburg, wil ik bedanken voor de ondersteuning bij de vestiging van deze leerstoel aan de UM. Ik hoop dat het Trimbos-instituut een nieuwe programmaleider Antisociaal Gedrag zal vinden, waardoor de onder- 
zoeklijn gecontinueerd kan worden, en kruisbestuiving met het universitaire onderzoek kan plaatsvinden.

Lieve collega's, vrienden en familie, velen van jullie hebben ver gereisd om hier vandaag te zijn en dat waardeer ik. Zonder iemand tekort te willen doen, noem ik speciaal de collega's van het CARE-NL- en het PMTO-project, met wie ik nog lang hoop samen te werken. Mijn moeder en mijn broer Pim en zijn gezin komen uit Enschede. Ik wil jullie bedanken voor jullie nieuwsgierige interesse in mijn werk, en Pim in het bijzonder voor de vele mooie ontwerpen en het geduld met mijn perfectionisme. Mijn goede vienden Leo, Christine en André, ik hoop nog lang te kunnen genieten van onze inspirerende gesprekken en van jullie kritische feedback op mijn media-optredens. Ferkó en Julian, voor jullie brengt mijn vierdaagse werkweek in Maastricht natuurlijk de meeste verandering teweeg. Ik realiseer mij dat ik offers van jullie vraag. Ferkó, jij geeft mij altijd het vertrouwen dat er een betere wereld mogelijk is, als je strijdbaar bent als een Jeanne d'Arc en compassievol zoals een Florence Nightingale . Julian, jij hebt mij toen je acht jaar was een keer 'professor calamiteit' genoemd, toen ik weer eens op de televisie kwam na een incident met een TBS-er. Dit jaar waren we samen op jouw verjaardag bij Philip Freriks op het achtuur journaal, voor ons beiden een bijzondere ervaring. Ik verheug me nu al op onze reis samen naar Barcelona in de herfstvakantie.

Tenslotte ben ik mijn leermeester Alexander Smit oneindig dankbaar voor zijn wijsheid. Hij stelde vaak die ene vraag: "Heb je iets beters te doen?"

Ik heb niets beters te doen.

Ik heb gezegd. 


\section{Literatuur}

Andrews, D.A., \& Bonta, J. (2003). The psychology of criminal conduct (3rd ed.). Cincinnati, $\mathrm{OH}$ : Anderson.

Aos, S., Miller, M., \& Drake, E. (2006). Evidence-based public policy options to reduce future prison construction, criminal justice costs, and crime rates. Olympia: Washington State Institute for Public Policy.

Barnoski, R. (2002). Washington State's implementation of Functional Family Therapy for juvenile offenders: Preliminary findings. Olympia: Washington State Institute for Public Policy.

Bechara, A., Damasio, H., Tranel, D., \& Damasio, A.R. (1997). Deciding advantageously before knowing the advantageous strategy. Science, 275, 293-295.

Bechara, A., Dolan, S., \& Hindes, A. (2002). Decision-making and addiction (Part II): Myopia for the future or hypersensitivity to reward. Neuropsychologia, 40, 1690-1705.

Berger, M., \& van Everdingen, J. (2006). De positionering van PMTO ten opzichte van andere intensieve ouderinterventies in Nederland. Utrecht: NIZW. Vindplaats: www.nederlandsjeugdinstituut.nl.

Blair, R.J. (1995). A cognitive developmental approach to morality: Investigating the psychopath. Cognition, 57, 1-29.

Blair, R.J. (2001). Neurocognitive models of aggression, the antisocial personality disorders, and psychopathy. Journal of Neurology, Neurosurgery and Psychiatry, 71, 727-731.

Blair, R.J.R. (2003). Neurobiological basis of psychopathy. British Journal of Psychiatry, 182, 5-7.

Blair, R.J., Colledge, E., \& Mitchell, D.G. (2001). Somatic markers and response reversal: Is there orbitofrontal cortex dysfunction in boys with psychopathic tendencies? Journal of Abnormal Child Psychology, 29, 499-511. 
Birbaumer, N., Veit, R., Lotze, M., Erb, M., Hermann, C., Grodd, W., \& Flor, H. (2005). Deficient fear conditioning in psychopathy: A functional magnetic resonance imaging study. Archives of General Psychiatry, 62, 799-805.

Boone, M. (2007). Nieuwe ficties in het gevangeniswezen. Differentiatie en resocialisatie in De Nieuwe Inrichting. Proces: Tijdschrift voor Strafrechtspleging, 86, 82-89.

Boone, M., \& Moerings, M. (2007). De cellenexplosie:Voorlopig gehechten, veroordeelden, vreemdelingen, jeugdigen en tbs. Justitiële Verkenningen, 33, 9-30.

Brand, E. (2001). Het persoonlijkheidsonderzoek in het strafrecht. Deventer: Gouda Quint.

Breuk, R.E.,van Dam, A., Disse, C.M., \& Doreleijers, T.A.H. (2005). Functionele Gezinstherapie in de behandeling van jeugdige forensisch psychiatrische patiënten. In: C. de Ruiter \& M. Hildebrand (Red.), Behandelingsstrategieën bij forensisch psychiatrische patiënten. Tweede, geheel herziene druk. Houten/Diegem: Bohn Stafleu Van Loghum.

Brown, B.S., O'Grady, K.E., Battjes, R.J., Farrell, E.V., Smith, N.P., \& Nurco, D.N. (2001). Effectiveness of a stand-alone aftercare program for druginvolved offenders. Journal of Substance Abuse Treatment, 21, 185-192.

Bulten, B.H. (1998). Gevangen tussen straf en zorg: Psychische stoornissen bij jeugdige, kortgestrafte gedetineerden. Deventer: Kluwer.

Bulten, B.H., \& van Kordelaar, W.F.J.M. (2005). Zorg in detentie. In E.R. Muller \& P.C. Vegter (Red.), Detentie: Gevangen in Nederland. Alphen aan den Rijn: Kluwer.

Burns, K., \& Bechara, A. (2007). Decision making and free will: A neuroscience perspective. Behavioral Sciences and the Law, 25, 263-280.

Bush, S.S., Connell, M.A., \& Denney, R.L. (2006). Ethical practice in forensic psychology: A systematic model for decision making. Washington, DC: American Psychological Association. 
Carey,P.(2007).A briefhistory of the concept of free will: Issues that are and are not germane to legal reasoning. Behavioral Sciences and the Law, 25, $165-181$.

Carnahan, T., \& McFarland, S. (2007). Revisiting the Stanford Prison Experiment: Could participant self-selection have led to the cruelty? Personality and Social Psychology Bulletin, 33, 603-614.

Committee on Ethical Guidelines for Forensic Psychologists. (1991). Specialty guidelines for forensic psychologists. Law and Human Behavior, $15,655-665$.

Crombag, H.F.M., van Koppen, P.J., \& Wagenaar, W.A. (2005). Dubieuze zaken: De psychologie van strafrechtelijk bewijs (derde druk). Amsterdam: Olympus.

Damasio, A. (2003). Het gelijk van Spinoza: Vreugde, verdriet en het voelende brein. Amsterdam: Wereldbibliotheek.

Deeley, O., Daly, E., Surguladze, S., Tunstall, N., Mezey, G. et al. (2006). Facial emotion processing in criminal psychopathy: Preliminary functional magnetic resonance imaging study. British Journal of Psychiatry, $189,533-539$.

Derks, W. (2001). Het oordeel van Hippias: Over de deskundigheid van psychiaters en psychologen en hun invloed op de strafrechtspraak. Amsterdam: De Arbeiderspers.

Forgays, D.K., \& DeMilio, L. (2005). Is Teen Court effective for repeat offenders? A test of the restorative justice approach. International Journal of Offender Treatment and Comparative Criminology, 49, 107-118.

Gezondheidsraad (2006). Preventie en behandeling van de antisociale persoonlijkheidsstoornis. Den Haag: Gezondheidsraad.

Gudjonsson, G.H., \& Young, S. (2006). An overlooked vulnerability in a defendant: Attention deficit hyperactivity disorder and a miscarriage of justice. Legal and Criminological Psychology, 11, 211-218. 
Haney, C. (2006). Reforming punishment: Psychological limits to the pains of imprisonment. Washington, DC: American Psychological Association.

Haney, C., Banks, W., \& Zimbardo, P. (1973). Interpersonal dynamics in a simulated prison. International Journal of Criminology and Penology, 1, 69-97.

Haney, C., \& Zimbardo, P. (1998). The past and future of U.S. prison policy: Twenty-five years after the Stanford Prison Experiment. American Psychologist, 53, 709-727.

Harvey, E., Shakeshaft, A., Hetherington, K., Sannibale, C., \& Mattick, R.P. (2007). The efficacy of diversion and aftercare strategies for adult druginvolved offenders: A summary and methodological review of the outcome literature. Drug and Alcohol Review, 26, 379-287.

Hildebrand, M., \& de Ruiter, C. (2004). Gestructureerde risicotaxatie: een noodzakelijke bezigheid in de tbs. Reactie op Deenen. Gedragstherapie, 37, 49-53.

Inspectie voor Sanctietoepassing (2007). Inspectiejaarbericht 2006. Den Haag: Ministerie van Justitie.

Jelicic, M., \& Merckelbach, H.L.G.J. (2006). Waarom de werkwijze van het Pieter Baan Centrum aan herziening toe is. Ars Aequi, 55, 265-268.

Kiehl, K.A., Smith, A.M., Hare, R.D., Mendrek, A., Forster, B.B., Brink, J., \& Liddle, P.F. (2001). Limbic abnormalities in affective processing by criminal psychopaths as revealed by functional magnetic resonance imaging. Biological Psychiatry, 50, 677-684.

Koss, M.P., Bachar, K.J., Hopkins, C.Q.., \& Carlson, C. (2004). Expanding a community's justice response to sex crimes through advocacy, prosecutorial, and public health collaboration: Introducing the RESTORE program. Journal of Interpersonal Violence, 19, 1435-1463.

Libet, B. (1985). Unconscious cerebral initiative and the role of conscious will in voluntary action. Behavioral and Brain Sciences, 8, 529-566. 
McGuire, J. (2002). (Ed.). Offender rehabilitation and treatment: Effective programs and policies to reduce re-offending. Chichester, UK: Wiley.

Limbos, M.A., Chan, L.S., Warf, C., Schneir, A., Iverson, E., Shekelle, P., \& Kipke, M.D. (2007). Effectiveness of interventions to prevent youth violence: A systematic review. American Journal of Preventive Medicine, 33, 65-74.

Milgram, S. (1963). Behavioral study of obedience. Journal of Abnormal and Social Psychology, 67, 371-378.

Poort, R. (2007). Het reclasseringsbeleid van Minister Donner. Ontwikkelingen in de jaren 2002-2006 (en daarvoor). Proces: Tijdschrift voor Strafrechtspleging, 86, 90-97.

RMO (2007). Straf en zorg: Een paar apart. Passende interventies bij delictplegers met psychische en psychiatrische problemen. Amsterdam: Uitgeverij SWP.

Rosenhan, D.L. (1973). On being sane in insane places. Science, 19, 250258.

Ruiter, C. de (2000). Voor verbetering vatbaar. Rede uitgesproken bij de aanvaarding van het ambt van bijzonder hoogleraar in de Forensische psychologie aan de Universiteit van Amsterdam. Amsterdam:Vossiuspers AUP.

Ruiter, C., de (2006). Huiselijk geweld: van signalering tot een effectieve aanpak. Tijdschrift Sociaal Psychiatrische Verpleegkunde, 25, 7-14.

Ruiter, C., de (2007a). Een dubieuze gedragskundige rapportage bij een ontkennende verdachte. De casus van de Anjummer pensionmoorden. Proces: Tijdschrift voor Strafrechtspleging, 86, 136-145.

Ruiter, C., de (2007b). Over risicofactoren, effectieve interventies en inconsistent overheidsbeleid inzake geweldscriminaliteit. In: A.M. van der Laan, L. Vervoorn, N. van Nimwegen \& F.L. Leeuw (Red.), Justitie en demografie: Veranderingen in bevolkingssamenstelling en de gevolgen voor Justitie (pp. 157-168). Den Haag: WODC. 
Ruiter, C., de (2007c). (Sociale) leertheorie: De remedie tegen antisociaal gedrag. Bijdrage aan een bundel ter gelegenheid van het 30-jarig bestaan van de Vereniging voor Gedragstherapie en Cognitieve Therapie, in druk.

Ruiter, C., de, \& Hildebrand, M. (2003). The dual nature of forensic psychiatric practice: Risk assessment and management under the Dutch TBSorder. In: P.J. van Koppen \& S.D. Penrod (Eds.), Adversarial vs. inquisitorial justice: Psychological perspectives on criminal justice systems (pp. 91-106). New York: Plenum Press.

Ruiter, C., de, \& de Jong, E.M. (2006). CARE-NL: Richtlijn voor gestructureerde beoordeling van het risico van kindermishandeling. Utrecht: C. de Ruiter.

Ruiter, C., de, \& Hildebrand, M. (2007). Risk assessment and treatment in Dutch forensic psychiatry. Netherlands Journal of Psychology, in press.

Ruiter, C., de, \& Öry, F.G. (2006). A screening tool for risk of child abuse by front line workers: Development and pilot validation research of the MiniCARE. Projectaanvraag.

Ruiter, C., de, \& Veen, V. (2005). Terugdringen van recidive bij geweldsdelinquenten: Werkzame interventies bij relationeel, seksueel en algemeen geweld. Utrecht: Trimbos-instituut.

De Ruiter, C., Veen, V., \& Greeven, P.G.J. (2005). De effectiviteit van psychologische behandeling bij verkrachters: Bevindingen van een meta-analyse. Utrecht: Expertisecentrum Forensische Psychiatrie.

Schoemaker, C., \& van Zessen, G. (1997). Psychische stoornissen bij gedetineerden: Een verkennend onderzoek in Penitentiair Complex Scheveningen. Utrecht: Trimbos-instituut.

Slobogin, C. (2007). Proving the unprovable: The role of law, science and speculation in adjucating culpability and dangerousness. New York: Oxford University Press. 
Snippe, J., van der Stoep, R., van Zwieten, M., \& Bieleman, B. (2006). Lokale aanpak zeer actieve veelplegers: Nazorgtraject. Groningen-Rotterdam: Intraval.

Struijk, S. (2007). Het veelplegersbeleid van Donner: Spagaat tussen beveiliging en resocialisatie. Proces: Tijdschrift voor Strafrechtspleging, 86, 106-116.

Swanson, J.W., Swartz, M.S., Borum, R., Hiday, V.A., Wagner, H.R., \& Burns, B.J. (2000). Involuntary out-patient commitment and reduction of violent behavior in persons with severe mental illness. British Journal of Psychiatry, 176, 324-331.

Tiihonen, J., Hodgins, S., Vaurio, O. et al. (2000). Amygdaloid volume loss in psychopathy. Society for Neuroscience Abstracts, 2017.

Vliet, J.A. van, \& Oei, K. (2006). Van stoornis naar delict: De verbrokkelde hulpverleningsgeschiedenissen van tbs-gestelden. Pedagogiek, 26, 301316.

Walgrave, L. (2005). Naar beginselen van een behoorlijke herstelrechts bedeling. In F. Verbruggen, B. van Dale \& B. Spriet (Red.), Strafrecht als roeping-Liber Amicorum Lieven Dupont. Leuven: Universitaire Pers Leuven.

Wegner, D.M., \& Wheatley, T. (1999). Apparent mental causation: Sources of the experience of will. American Psychologist, 54, 480-492.

Zwemmer, J., Jager, J., \& van Vliet, J.A. (2007). Nazorg in ontwikkeling: Werk in uitvoering! Proces: Tijdschrift voor Strafrechtspleging, 86, 117-123. 


\section{Noten}

${ }^{1}$ Boone en Moerings verwoorden het treffend in de slotzin van hun artikel: "De conclusie moet dan zijn dat Nederland van een land dat bekend stond om zijn tolerantie ten opzichte van afwijkend gedrag, verworden is tot een land dat zijn problemen met minderheidsgroepen en probleemgroepen oplost door hen op te sluiten" (p. 28).

${ }^{2}$ De Inspectie voor de Sanctietoepassing uit zich in haar laatste inspectierapport over 2006 (februari 2007) kritisch over de doorgevoerde maatregelen. Zij wijst er bijvoorbeeld op dat door de krappe personele besetting en verkorting van het dagprogramma artikel 51.2 van de European Prison Rules in het geding kan komen: "The security which is provided by physical barriers and other technical means shall be complemented by the dynamic security provided by an alert staff who know the prisoners who are under their control".

3 SOV staat voor Starfrechtelijke Opvang Verslaafden, zie o.a. Van 't Land, H., van Duijvenbooden, van der Plas, A., \& Wolf, J. (2005). Opgevangen onder dwang: Proces-evaluatie strafrechtelijke opvang verslaafden. Utrecht: Trimbosinstituut.

${ }^{4}$ ISD staat voor Inrichting voor Stelselmatige Daders.

${ }^{5}$ Zie ook het recente boek van Cornelie van Well (2007), Een kwetsbaar mens: 17 verhalen uit de forensische psychiatrie. Utrecht: de Tijdstroom, met illustratieve, maar schrijnende schetsen van de teleurstelling in de Nederlandse hulpverlening van ouders van gedetineerden en TBS-gestelden.

${ }^{6}$ Het interview is na te lezen via www.elsevier.nl/nieuws/wetenschap/artikel/ asp/artnr/129054/.

${ }^{7}$ Naast het beruchte experiment van Stanley Milgram (1963), dat aantoonde dat psychisch gezonde mensen onder invloed van autoriteit bereid waren dodelijke electrische schokken toe te dienen, is het Stanford gevangenisexperiment een van de bekendste uit de sociale psychologie.

${ }^{8}$ Een recente studie van Carnahan en McFarland (2007) laat zien dat bij de recrutering van de proefpersonen voor het Stanford Prison Experiment mogelijk zelfselectie een rol heeft gespeeld. Uit hun experiment bleek dat vrijwilligers voor een psychologisch onderzoek 'naar het leven in een gevangenis' significant hoger scoorden op aggressiviteit, narcisme, Machiavellisme en sociale dominantie, en significant lager op empathie en altruïsme, dan vrijwilligers die opgeroepen werden voor een psychologisch onderzoek zonder de toevoeging 'naar het leven in een gevangenis'. Deze auteurs verklaren de dramatische afloop van het Stanford Prison Experiment dan ook vanuit een persoon-situatie interactie model: mensen kiezen (en vermijden) situaties die bepaald gedrag versterken. Toch doet deze interpretatie niets af aan de kracht van de nep-gevangenis, of de echte gevangenis, om (bij bepaalde daarvoor gevoelige mensen) mishandeling uit te lokken.

9 Recent verscheen het boek Reforming punishment: Psychological limits to the pains of imprisonment, van de hand van Craig Haney (2006), de student die promoveerde op het Stanford Prison Experiment. Naast een schets van de psychologische schade die de gevangenisomgeving aan de mens die erin moet 
verblijven kan toebrengen, biedt het boek uitzicht op alternatieve strategieën. Het laatste hoofdstuk van het boek heeft dan ook als titel: Limiting prison pain: A psychologically informed corrections agenda. Ik zou willen zeggen: verplichte kost voor beleidsmakers op het terrein van het gevangeniswezen.

${ }^{10}$ Frye vs. United States, 293 F. Supp. 1013 (D.C. Circ. 1923).

"Daubert vs. Merrell Dow Pharmaceuticals, 113 Supreme Court 2786.

${ }^{12}$ Een voorbeeld van het ontbreken van objectiviteit in de Nederlandse forensische gedragskundige rapportages is het feit dat er vrijwel nooit rivaliserende hypothesen in worden beschreven, of dat er beperkingen aan de diagnostische conclusies in worden aangegeven. De Specialty Guidelines voor Forensic Psychologists wijzen uitdrukkelijk op de noodzaak hiervan: "As an expert conducting an evaluation, treatment, consultation, or scholarly-empirical investigation, the forensic psychologist maintains professional integrity by examining the issue at hand from all reasonable perspectives, actively seeking information that will differentially test rival hypotheses" (SGFP VI, A2, Methods and Procedures)

${ }^{13}$ Uiteraard is er nog veel imperfect aan de huidige classificatiesystemen, maar dat doet niets af aan het feit dat zij in ieder geval enige garantie bieden op een objectieve, transparante wijze van diagnosticeren.

${ }^{14} \mathrm{Na} 8$ jaar heeft driekwart van de ex-gedetineerden een nieuw justitiecontact, meestal wegens het plegen van een misdrijf met een wettelijke strafdreiging van 4 tot 8 jaar (Wartna, Tollenaar, \& Essers, 2005). Uit nog recenter onderzoek blijkt dat het percentage ex-gedetineerden dat binnen 2 jaar opnieuw voor een misdrijf werd vervolgd in de periode 1996-2003 schommelde tussen 54 en 59 procent (Wartna, Kalidien, Tollenaar, \& Essers, 2006). Bij ex-ter beschikking gestelden ligt het percentage algemene recidive na 2 jaar voor verschillende cohorten tussen 20 en 45 procent (Wartna, el Harbachi, \& Essers, 2006). Zie: www.wodc.nl. 
